\title{
The Dynamic Relationship between Globalization and Economic Growth: Its Implication on Business Policy
}

\author{
Rima Midiyanti ${ }^{\mathrm{a} *}$ and Ming-Hung $\mathrm{Yao}^{\mathrm{b}}$ \\ ${ }^{a}$ Lecturer, Department of Business Administration, Politeknik Negeri Bandung, Bandung, Indonesia \\ ${ }^{\mathrm{b}}$ Associate Professor, College of Management, National Kaohsiung University of Applied Sciences, \\ Taiwan
}

Received 3 November 2018; accepted 7 June 2019

\begin{abstract}
The purpose of this study is to investigate the relationships between globalization and economic growth in Indonesia. Three globalization indices, economic globalization index, social globalization index and political globalization index, are used to measure the globalization. Johansen's (1988) cointegration approach was used to estimate the model by using annual data from 1980 to 2014. The results indicate that there is a long-run cointegration relationship between globalization and economic growth in Indonesia. Globalization stimulates Indonesian economic growth in the long run. Meanwhile, political globalization implies short-run effect on the economic growth in Indonesia. From the policy perspective, this results support the argument that the government should take the international integration policy to sustain long-run economic growth.
\end{abstract}

\section{KEYWORDS}

Globalization

Economic growth

Business policy

\section{INTRODUCTION}

Globalization becomes a complex issue particularly while weighting its benefits and disadvantages. The opponents of globalization say that it can raise inequality between the rich and the poor. However, the supporters of economic globalization argue that those who care about the poor should appreciate the economic globalization. It is because liberalization increases flows of trade and finance that lead to higher income and allow the poor to have a better living condition (Nayyar, 2009).

Numerous studies have examined the link between economic growth and globalization on various sectors. A study examines the impact of banking sector globalization on economic growth (Ghosh, 2017). Further, different sustainability aspects of globalization which are economic, environmental and social impact have been analyzed in coastal Peru (Schwarz \& Mathijs, 2017). A study about globalization also has been discussed related to many other sectors. The cointegration among tourism, globalization and economic growth is investigated for several West African States (Salifou \& Haq, 2017). The impact of globalization and economic growth on energy consumption has also been assessed in Brazil, Russia, India and China (Dogan \& Deger, 2016). Moreover, the economic growth, urbanization, globalization and the risks of emerging infectious disease have also been analyzed in China (Wu et al., 2017). 
Although many studies discuss about the impact of globalization on economic, social and political sectors, there is only a few empirical studies analyzing the effect of economic, social and political globalization on economic development. Reviewing the literature, most of the studies about globalization use panel data. Unlike the previous research, this study focuses on time-series study about globalization and economic growth in Indonesia. Besides giving deep analysis on a single country, an empirical study on a single country is also scarce. However, there are some studies on the single country in regard with globalization by using various measurements.

Regarding the period of time, there are numerous studies which examine the long-term effect of globalization on economic growth. A panel causality study has been revisited for globalization and economic growth in 9 OECD countries and China, which focuses on the long-run effect (Chu, Chang, \& Sagafi-nejad, 2016). The globalization and Chinese growth have been assessed to see the longterm trend on the global economy (Lo, Hong, \& Li, 2016). Another contribution on the study is filling the gap in this area. The study explains an error correction term among the variables which focuses on the Indonesian case. As a multicultural country with hundreds of ethnics and local languages, globalization may have direct impact on Indonesia. Many developing countries concern about the increase of globalization due to its impact which might destroy their own cultures, tradition, identities, customs and languages (Hamdi, 2013).

Based on the above explanation, the purpose of the study is to investigate the long-run and shortrun dynamic analysis association among three indices of globalization and economic growth in Indonesia. Knowing the relationship and the role between economic growth and the globalization helps the government implicate a good policy in order to accelerate economic growth of Indonesia.

\section{LTERATURE REVIEW}

Numerous studies have examined the globalization as a determinant of economic growth with different indicators. The globalization is usually reflected as an increase in trade, openness or liberalization. A study finds that GDP growth rates have seen some improvement in African countries which imply trade liberalization and export-led growth strategies (Ahmed, Cheng, \& Messinis, 2011). Furthermore, the relationship between globalization and economic growth has also been investigated through foreign direct investment (FDI) (Moghaddam \& Redzuan, 2012).

Despite the fact that most of studies use trade, foreign direct investment and capital flows or openness as the indicators of globalization, the measurement seems not enough to indicate globalization. The rate of protection and tariff needs to be considered while measuring the globalization since they are the policies based variables (Samimi \& Jenatabadi, 2014). In order to make a comprehensive study, this research uses an index of globalization called $K O F$ (Konjunkturforschungsstelle). This index is introduced by Dreher (2006) while assessing the impact of globalization on growth in 123 countries. The study finds that economic and social aspects have a positive impact on economic growth (Dreher, 2006). However, political aspect has no effect on economic growth. Its robustness is supported by another study which uses the index to investigate the impact of globalization on growth rate for 21 African countries (Rao \& Vadlamannati, 2011). The result indicates that the positive effect of globalization on growth is larger than the effect of investment on growth. Furthermore, using general index of globalization (KOF Index of Globalization, 2014), the components, which are the economic globalization, social globalization and political globalization, account for 36\%, 38\% and 26\% (Dreher, Gaston, \& Martens, 2008). The explanation of these 3 components are:

1. Economic Globalization

This index consists of 2 sub-indexes that are actual flows and restrictions. The actual flows 
are calculated from the ratios of trade, foreign direct investment, portfolio investment and income payments to foreign national over GDP. Restrictions are calculated from hidden import barriers, average tariff rate, taxes on international trade and capital account restrictions.

2. Social Globalization

This index includes 3 sub-indexes which are personal contact, information flows and cultural proximity. Personal contact is calculated from telephone traffic, the ratio of transfers over GDP, international tourism, total population percentage of foreign population and international letters per capita. Information flow is calculated from internet usage per 1000 people, television per 1000 people and international newspapers traded (in percent of GDP). Cultural proximity is calculated from the number of McDonald's restaurants per capita, the number of Ikea per capita and traded books.

3. Political Globalization

This index is calculated from the number of embassies in the country, membership in international organizations, participation in United Nations Security Council Missions and international treaties.

Some studies use the KOF index as a comprehensive indicator of globalization. A study examines the effects of globalization on economic growth for developing countries (Kilic, 2015). The impact of globalization on economic growth of ASEAN countries has been discussed as well. The study finds that economic globalization has a positive influence on economic growth while the social globalization has a negative influence on economic growth. In the case of political globalization, it has a non-significant negative effect on economic growth (Ying, Chang, \& Lee, 2014). Moreover, the study about the effect of economic globalization on the economic growth in OIC countries finds that high and middle-income countries benefit from globalization while low-income countries do not (Samimi \& Jenatabadi, 2014).

The role of globalization toward a country's development has been widely investigated either directly or indirectly. An investigation has been analyzed for globalization, wage shares, and income distribution in Turkey (Oyvat, 2010). The successful economic development of a country is also affected by its ability to globalize (Levy, 2012). Others argue that globalization helps developing countries to deal with the rest of the world and increase their economic growth (Hamdi, 2013). In addition, the higher economic growth in Turkey is a result of trade openness with higher salary inequality (Elveren, Örnek, \& Akel, 2012). Further, there is also a study about globalization and economic growth in India. It finds that the private investment, openness, human resource development and financial integration (capital inflow and capital outflow) have a long run cointegration to economic growth through GDP growth (Ray, 2012).

Indonesia as a developing country seems to have a good prospect in economic condition. Regarding the last three years, its economic growth rate reaches almost 7 percent. In addition, Indonesia proved that it could survive in the financial crisis in 2008. Comparing to another big economic crisis in 1997/1998 in which Indonesian economic growth rate was -13 percent, Indonesia managed the positive economic growth rate around 5 to 6 percent during the financial crisis 2008/2009 (Tambunan, 2010). Despite the fact that the globalization's effect has been so concerned, political system has a role to implicate a solution. 


\section{METHODOLOGY}

The study employed Johansen cointegration approach in order to see long-run cointegration between variables. Moreover, Vector Error Correction Model (VECM) and Granger Causality were performed to examine short-run dynamics of its relationship. It used a simple linier regression equation.

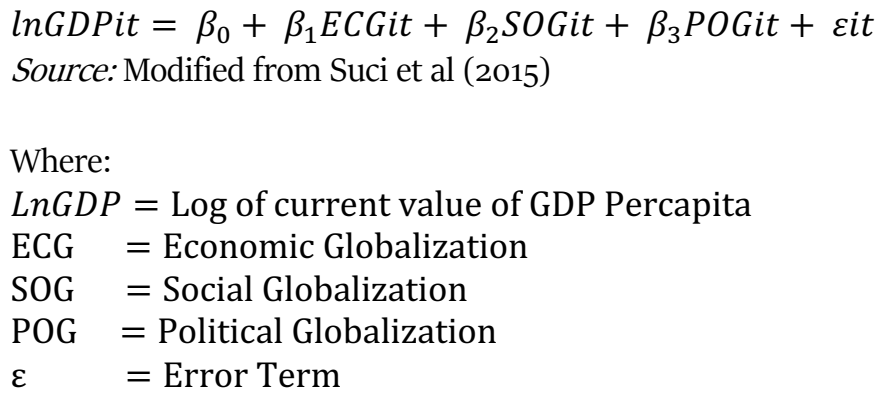

\section{Unit Root Test}

Before conducting the cointegration testing, it is essential to check the stationarity of the data. If there is a unit root in the data, the data then become non-stationary. Dealing with unit root testing, it is important to know the order of integration in order to choose appropriate method for regression. The process is said to be stationary if its probability distribution remains unchanged as time proceeds and it can be said that data generation process steady (Chiawa, Torruam, \& Abur, 2012).

Considering the availability of unit root, this study examined the stationarity data by using Augmented Dickey Fuller (ADF) Test and Philips and Perron (PP) Test. These unit root tests are initially performed to find the stationarity properties of the each time-series (Dickey \& Fuller, 1981; Phillips \& Perron, 1988). These tests took the null hypothesis $\left(H_{0}\right)$ against the alternative hypothesis $\left(H_{1}\right)$ for this model as follow:

$H_{0}: \beta=o$ (unit root exists)

$H_{1}: \beta<\mathrm{o}$ (no unit root exists)

The estimation based on non-stationary series may lead to spurious regressions (Granger, 1969). Since non-stationary time series do not return to their long run average value following a disturbance, it is important to convert them to stationary process because regressing one nonstationary series to another non-stationary series may lead to spurious results (Iqbal, 2011).

\section{Johansen Cointegration Test}

Cointegration is a long-run equilibrium concept between two or more economic variables. The concept of cointegration in which economic variables might reach a long-run equilibrium that reflects a stable relationship among them was introduced in 1987 (Engle \& Granger, 1987). There is an approach to investigate long-run relationship among non-stationarity variables (Johansen, 1988). If all of series are stationary, the cointegration does not exist. Therefore, the test used to determine cointegration in this study is called Johansen Cointegration Approach and used the maximum likelihood procedure (Johansen, 1991; Soren, 1995). This approach can be run if at least the two non- 
stationary variables are cointegrated as I (1). Ignoring the existence of cointegration can lead to serious model of misspecification (Toda \& Phillips, 1993).

The Johansen approach can determine the number of cointegrated vectors for any given number of non-stationarity variables of the same order (Ray, 2012). The technique number of cointegrating vectors must be well identified. They include trace statistics as well as maximum eigen value (Johansen \& Juselius, 1990). The likelihood ratio trace statistic of the null hypothesis is that there are $h$ cointegrating vectors against the alternative $(n)$ which given by:

$$
\lambda \operatorname{trace}(\mathrm{r})=-\mathrm{T} \sum_{i=r+1}^{g} \ln (1-\lambda \mathrm{i})
$$

The likelihood ratio maximumeigenvalue statistic of the null hypothesis is that there are $h$ cointegrating relations against the alternative $(\mathrm{h}+1)$ that can be shown as follow.

$$
\lambda_{\max }(r)=-T \ln \left(1-\lambda_{r+1}\right)
$$

\section{Vector Error Correction Model (VECM)}

Error Correction is a means of reconciling the short run behavior (or value) of an econometric variable with its long-run behavior (or value). Error correction term was first used by Sargan in 1964 (Sargan, 1964) then adopted, modified and popularized (Engle \& Granger, 1987). The cointegrated time series data represent an error correction that shows short-run adjustment. The causality has to exist, at least, in one direction if the variables are I(1) and it is then augmented with an error correction term (Engle \& Granger, 1987). The cointegration term is known as the error correction term since the deviation from long-run equilibrium is corrected gradually through a series of partial short-run adjustments. The size of the error correction term indicates the speed of adjustment of any disequilibrium towards a long-run equilibrium state. Based on the representation theorem (Engle \& Granger, 1987), the error correction model of equation is formulated as follows :

$$
\Delta \operatorname{lnLGDP_{t}}=\alpha+\lambda E C M_{t-i}+\sum \beta_{i} \Delta \operatorname{lnLGDP_{t-i}}+\sum \Psi_{i} \Delta \ln E C G_{t-i}+\sum \varphi_{i} \Delta \operatorname{lnSOG} G_{t-i}+\sum \eta_{i} \Delta \ln P O G_{t-i}+\mu_{t}
$$

The present of $\mathrm{ECM}_{\mathrm{t}-\mathrm{i}}$ shows that there is short-run adjustment to correct any disequilibrium in the long-run. It represents the presumption that the dependent variable does not adjust immediately to its long-run determinants.

\section{RESULTS}

This section shows the empirical results of the research which is begun with the regression linier model. Next, it is continued with the explanation of Johansen Cointegration Test and Vector Error Correction Model. The regression linier model can be shown as follow.

$$
Y=3.266+0.006 E C G-0.013 S O G+0.050 P O G
$$

The result shows that economic globalization has a positive non-significant relationship with the economic growth. On the other hand, there is a negative non-significant relationship between social globalization and economic growth. In regard with political globalization, it has a positive significant relationship with economic growth. 


\section{The Result of Unit Root Testing}

Several unit root tests have been developed in time series econometrics studies. It is important to check the stationarity since the time-series data tend to exhibit a deterministic and/or stochastic trend. Before checking the stationarity, it is important to choose the appropriate lag for the model. There are some tests which can be used to see the most appropriate lag.

Table 1. Lag selection results

\begin{tabular}{ccccccc}
\hline Lag & LogL & LR & FPE & AIC & SC & HQ \\
\hline o & -301.876 & NA & 4370.098 & 19.733 & 19.919 & 19.794 \\
1 & -190.524 & 186.784 & 9.413 & 13.582 & $14.507^{*}$ & 13.884 \\
2 & -177.603 & 18.340 & 12.159 & 13.781 & 15.446 & 14.324 \\
3 & -144.458 & $38.491^{*}$ & $4.681^{*}$ & 12.675 & 15.080 & $13.459^{*}$ \\
4 & -127.992 & 14.872 & 6.263 & $12.645^{*}$ & 15.790 & 13.670 \\
\hline
\end{tabular}

Note: * indicates lag order selected by the criterion

As can be seen on Table 1, there are several suggestions given in choosing the most appropriate lag. AIC test suggests using lag 4 for the model, but SC test recommends choosing lag 1. Other three tests suggest lag 3. So, lag 3 was chosen in the model. After that, the LM test was conducted to check if there was an autocorrelation of the errors in the regression model. The null hypothesis of this test shows that there is a serial correlation of residual. The result on Table 2 tells that the probability value is more than $5 \%$ and the null hypothesis cannot be rejected. It means that there is no serial correlation on the model. Then, stationary tests were conducted.

Most of the null hypothesis of these tests are to see whether there is a unit root or not. In regard with unit root test, this study checked the stationarity of the data by using Augmented Dickey Fuller (ADF) and Philips and Perron (PP). Table 2 presents the unit root testing results by ADF and PP respectively. Based on the results, it can be seen that the null hypothesis cannot be rejected at $1 \%$ significant level. Both of the tests indicate that all the variables have a unit root which means that they are not stationary in level. Further, the series are employed with unit root testing after taking the first difference. The first difference of a time-series is a series of changes from one period to the next.

The results of unit root tests after first difference determined by ADF and PP test captured that the unit root did not exist in the series. The null hypothesis of the variables is rejected at $1 \%$ significant level which means that they are stationary after the first difference is taken, except political globalization on the ADF test. It indicates that all the series are integrated of order one that is I (1). In other words, all of the variables are non-stationary at the level and stationary in the first difference. Therefore, Johansen Cointegration test was applied. 
Table 2. LM test results

\begin{tabular}{ccc}
\hline Lags & LM-Stat & Prob \\
\hline 1 & 12.176 & 0.732 \\
2 & 12.734 & 0.692 \\
3 & 10.838 & 0.819 \\
4 & 23.333 & 0.105 \\
5 & 22.856 & 0.118 \\
6 & 10.554 & 0.836 \\
7 & 8.145 & 0.944 \\
8 & 16.465 & 0.421 \\
9 & 11.084 & 0.804 \\
10 & 39.732 & 0.000 \\
11 & 7.546 & 0.961 \\
12 & 5.250 & 0.994 \\
\hline
\end{tabular}

Table 3. Result of unit root testing

\begin{tabular}{ccccc}
\hline \multirow{2}{*}{ Variables } & \multicolumn{2}{c}{ Augmented Dickey-Fuller } & \multicolumn{2}{c}{ Philips-Perron } \\
\cline { 2 - 5 } & Intercept & $\begin{array}{c}\text { Intercept and } \\
\text { Trend }\end{array}$ & Intercept & $\begin{array}{c}\text { Intercept and } \\
\text { Trend }\end{array}$ \\
\hline & \multicolumn{4}{c}{ LEVEL } \\
LGDP & $-0.025[0]$ & $-1.879[0]$ & $-0.007[1]$ & $-1.892[1]$ \\
ECG & $-1.026[0]$ & $-1.832[0]$ & $-1.066[3]$ & $-2.091[1]$ \\
SOG & $-1.310[0]$ & $-0.982[0]$ & $-1.308[2]$ & $-0.982[0]$ \\
POG & $-2.315[5]$ & $-1.936[5]$ & $-1.070[3]$ & $-1.771[2]$ \\
& & FIRST DIFFERENCE & \\
LGDP & $-5.690[0]^{* * *}$ & $-5.849[0]^{* * *}$ & $-5.690[1]^{* * *}$ & $-5.849[1]^{* * *}$ \\
ECG & $-4.614[0]^{* * *}$ & $-4.564[0]^{* * *}$ & $-4.560[3]^{* * *}$ & $-4.437[4]^{* * *}$ \\
SOG & $-5.303[0]^{* * *}$ & $-5.350[0]^{* * *}$ & $-5.299[2]^{* * *}$ & $-5.337[3]^{* * *}$ \\
POG & $-2.198[5]$ & $-3.159[5]$ & $-6.825[2]^{* * *}$ & $-6.965[4]^{* * *}$ \\
\hline
\end{tabular}

Note: The numbers in parentheses indicate the selected lag order. The null hypothesis $f$ for both tests is that variable which has a unit root. The superscript * $, * *, * * *$ denote significance at $10 \%, 5 \%$ and $1 \%$ respectively.

\section{The Result of Johansen Cointegration Testing}

Since the variables are I (1), the Johansen Cointegration can be applied to see whether the variables are cointegrated or having long-run association. The trace test and max-eigenvalue were conducted. The null hypothesis tested the number of cointegrating vector. As reported on Table 3, the maximum Eigen value test of at most 1, 2 and 3 cointegrating vectors cannot be rejected while the test of none cointegration has been rejected at 5\% significance level. In addition, the trace statistic indicates that there are 2 cointegrating vectors between variables.

The result of Johansen cointegration using max-Eigen value and trace statistic testing determines co-integrating vector between the variables. It means that there is a long-run equilibrium between economic growth and economic globalization, social globalization and political globalization. Moreover, based on the co-integrating vector equation, in the long run, social globalization has a positive relationship with economic growth, but the other two indices of globalization show reverse relationship with economic growth. 
The co-integrating equation vector can be shown as follow.

$$
Y=-0.019 E C G+0.324 S O G-0.291 P O G
$$

Table 4. Result of Johansen cointegration test

\begin{tabular}{ccccc}
\hline $\begin{array}{c}\text { Null } \\
\text { Hypothesis }\end{array}$ & $\begin{array}{c}\text { Alternative } \\
\text { Hypothesis }\end{array}$ & Test & $\begin{array}{c}95 \% \text { critical } \\
\text { value }\end{array}$ & Probability \\
\hline & & $\lambda_{\text {max }}$ \\
$\mathrm{r}=0$ & $\mathrm{r}=1$ & $31.603^{* * *}$ & 27.584 & 0.000 \\
$\mathrm{r}=1$ & $\mathrm{r}=2$ & 18.732 & 21.132 & 0.252 \\
$\mathrm{r}=2$ & $\mathrm{r}=3$ & 10.289 & 14.265 & 0.337 \\
$\mathrm{r}=3$ & $\mathrm{r}=4$ & 1.946 & 3.841 & 0.165 \\
& & $\lambda_{\text {trace }}$ & & \\
$\mathrm{r}=\mathrm{o}$ & $\mathrm{r}=\mathrm{o}$ & $62.571^{* * *}$ & 47.857 & 0.000 \\
$\mathrm{r} \leq 1$ & $\mathrm{r}>1$ & $30.967^{* * *}$ & 29.797 & 0.131 \\
$\mathrm{r} \leq 2$ & $\mathrm{r}>2$ & 12.234 & 15.495 & 0.255 \\
$\mathrm{r} \leq 3$ & $\mathrm{r}>3$ & 1.956 & 3.841 & 0.165 \\
\hline
\end{tabular}

Notes: Max-Eigen value tests and trace statistic indicate 1 and 2 cointegrating equation at the $1 \%$ level of significance respectively. $r$ indicates the number of cointegrating vector. $\lambda$ max and $\lambda$ trace are test statistic of maximum eigenvalue and trace statistic respectively.

\section{The Result of Vector Error Correction Model (VECM)}

The evidence of long-run equilibrium implies that there is an Error Correction Model (ECM) that combines the long-run relationship with short run dynamic model. Error Correction Model of this study is shown in table 4.5. Error correction term means that the deviation from long-run equilibrium is corrected gradually through series of partial short-run adjustments. The result shows that $\log$ of GDP and social globalization is significant at 5\% and $1 \%$ respectively. In other word, they will move together to make short-run adjustment from disequilibrium. This is an indirect effect between the variables.

Regarding the impact of GDP to the three variables, a causality effect has been recognized. First, in light of the direct causalities between GDP and three indices of globalization, ECG in lag 2 is significant at the $10 \%$ significant level. No other variables are affected by GDP. Furthermore, based on the result, it can be seen that there is only one variable, the political globalization, which has short-run direct effect to GDP. POG is statistically significant at $1 \%$ level. As three lags were used in this criterion, ECG does not directly cause SOG and POG. In addition, SOG does not directly cause ECG and POG. There is no either direct unidirectional or bidirectional effect between ECG and SOG. Moreover, POG has significant direct effect to ECG and SOG. So, there is a unidirectional direct effect between POG and ECG and also between POG and SOG.

This study also discusses an indirect effect between the variables, that is, the significances of the coefficients of error correction term, ECT. The results show that the coefficients of ECT for all of dependent variables, except for $\Delta$ (POG), are significant at $5 \%$ level. It implies that the two variables will indirectly cause GDP, that are ECG and SOG. Hence, considering both of direct and indirect effects of causality between GDP and other variables, there is bidirectional causality between GDP and ECG or between GDP and SOG. As to the causality between GDP and POG, POG leads GDP. 
Table 5. Vector error correction model

\begin{tabular}{ccccc}
\hline Independent & \multicolumn{4}{c}{ Dependent Variables } \\
\cline { 2 - 5 } Variables & $\Delta(\mathrm{LGDP})$ & $\Delta(\mathrm{ECG})$ & $\Delta(\mathrm{SOG})$ & $\Delta(\mathrm{POG})$ \\
\hline ECT & $-0.574[-3.035]^{* * *}$ & $6.688[2.003]^{* *}$ & $-2.065[-2.715]^{* * *}$ & $1.820[0.557]$ \\
$\Delta \mathrm{LGDP}(-1)$ & $0.350[1.163]$ & $6.477[1.219]$ & $1.941[1.603]$ & $-1.631[-0.313]$ \\
$\Delta \mathrm{LGDP}(-2)$ & $0.180[0.532]$ & $-9.841[-1.650]^{*}$ & $0.745[0.548]$ & $-2.880[-0.493]$ \\
$\Delta \mathrm{LGDP}(-3)$ & $0.477[1.489]$ & $-4.635[-0.820]$ & $0.332[0.258]$ & $-1.734[-0.313]$ \\
$\Delta \mathrm{ECG}(-1)$ & $-0.000[-0.013]$ & $0.719[2.219]^{* *}$ & $0.033[0.449]$ & $0.022[0.068]$ \\
$\Delta \mathrm{ECG}(-2)$ & $-0.004[-0.214]$ & $-0.411[-1.158]$ & $-0.052[-0.648]$ & $-0.047[-0.137]$ \\
$\Delta \mathrm{ECG}(-3)$ & $0.000[0.004]$ & $-0.081[-0.256]$ & $0.056[0.782]$ & $0.016[0.052]$ \\
$\Delta$ SOG(-1) & $-0.009[-0.410]$ & $-0.200[-0.531]$ & $0.122[1.426]$ & $0.265[0.719]$ \\
$\Delta$ SOG(-2) & $0.017[0.756]$ & $0.207[0.505]$ & $0.115[1.235]$ & $0.101[0.252]$ \\
$\Delta$ SOG(-3) & $-0.007[-0.307]$ & $-0.065[-0.153]$ & $-0.005[-0.061]$ & $-0.317[-0.759]$ \\
$\Delta$ POG(-1) & $-0.152[-2.757]^{* * *}$ & $1.766[1.814]^{*}$ & $-0.562[-2.532]^{* * *}$ & $0.288[0.302]$ \\
$\Delta$ POG(-2) & $-0.145[-2.767]^{* * *}$ & $1.809[1.956]^{*}$ & $-0.447[-2.123]^{* *}$ & $0.412[0.455]$ \\
$\Delta$ POG(-3) & $-0.124[-2.783]^{* * *}$ & $1.703[2.169]^{* *}$ & $0.188[1.053]$ & $0.465[0.604]$ \\
\hline
\end{tabular}

Note: The number in parentheses represent t-ratios. ${ }^{*},{ }^{* *},{ }^{* * *}$ denote significance at $10 \%, 5 \%$ and $1 \%$ respectively.

\section{DISCUSSION AND BUSINESS IMPLICATION}

This study investigates the impact of economic, social and political globalization on the Indonesian economic growth. Johansen's (1988) cointegration approach was used to assess the empirical evidence on the importance of globalization in order to sustain economic growth. The study used annual data from 1980 to 2014 and the main findings are summarized as follows.

First, the result of Johansen Cointegration testing indicates that there is a long-run association between economic, social, political globalization and economic growth in Indonesia. Second, there is a unidirectional direct effect between POG and ECG and also between POG and SOG. Moreover, ECG and SOG will indirectly cause GDP. Considering both of direct and indirect effects of causality between GDP and other variables, there is bidirectional causality between GDP and ECG or between GDP and SOG. As to the causality between GDP and POG, POG leads GDP.

The results of this study reveal that globalization boosts the economic growth. Foreign Direct Investment also affects economic growth in ten Commonwealth of Independent States (Azam \& Ahmed, 2015). A study examining the effect of economic globalization on the economic growth in OIC countries (Samimi \& Jenatabadi, 2014) reports that middle-income countries get benefit from globalization. Referring to this study findings, the government may take a strategy for promoting trade such as applying a lower tariff on imports. This policy will help to enhance Indonesian trade. During the New Order, Indonesia knew that it had a bad time which led to good policy. However, Indonesia nowadays has a bad time and bad policy when talking about the trade protectionism (Patunru \& Rahardja, 2015). An international trade may gain the profit from comparative advantage, slicing up the value chain, or economic scale. The smaller economists often have fewer competitive advantage that make them have less pressure which leads to the lack of creativity or innovation while providing the goods and services for customers. In the context of a global economy, multinational or bilateral trade helps to improve the economic activities. However, some gains may not be measured in economic statistics. For instance, the trade between countries involves a transfer of knowledge and technology. In addition, the activity often improves skills in management, production, finance, law and even allows the technological transfer between the countries. 
In regard with social globalization result, this factor indirectly causes economic growth. In this case, the government needs to improve international tourism policy and tourism infrastructure for attracting international tourists. Tourism stimulates economic growth in Malaysia (Tang \& Tan, 2015). An attractive international tourism sector should be promoted to accelerate economic growth as a study finds that tourism significantly contributes to Indian economic growth (Ohlan, 2017). Another study investigating the tourism-led growth in the top ten tourist destinations reports that tourism has positive relationship with economic growth. The weakest link on those factors are noted for China and Germany, possibly because of the limited importance of the tourism sector relative to other major economic activities in those countries (Shahzad, Shahbaz, Ferrer, \& Kumar, 2017). Their studies show that tourism has a little influence on economic growth.

Another important point identified from this study is that the political globalization has a significant role to promote economic growth. Taking this issue, this study suggests that Indonesian government should improve transparency and bureaucracy in the political environment. Further, as creating a safer and cleaner environment has a favorable impact on international investment, attention for development of a better environment is suggested. Finally, increasing international treaties hastens economic growth because more agreements mean more programs to solve poverty, education, economy and other problems. Thus, to be proactive in collaboration with other countries in various aspects is suggested.

\section{CONCLUSION AND FUTURE RESEARCH}

Globalization will affect many sectors. How much a country will suffer depends on its action towards the globalization. Indonesia nowadays faces ASEAN Economic Society. However, the responses for this free trade still remains debating. This study supports the economic globalization as a way to improve economic growth in Indonesia. Political globalization also has an important role to promote the economic growth. For the future research, applying other technique such as Impulse Response Function, Variance Decomposition and using the structural break will be recommended. Identifying the study with these techniques may give comprehensive understanding on how some phenomena affect the economic growth.

\section{REFERENCES}

Ahmed, A. D., Cheng, E., \& Messinis, G. (2011). The role of exports, FDI and imports in development: evidence from Sub-Saharan African countries. Applied Economics, 43(26), 3719-3731. doi:10.1080/00036841003705303

Azam, M., \& Ahmed, A. M. (2015). Role of human capital and foreign direct investment in promoting economic growth: evidence from Commonwealth of Independent States. International Journal of Social Economics, 42(2), 98-111.

Chiawa, M., Torruam, J., \& Abur, C. (2012). Cointegration and causality analysis of government expenditure and economic growth in Nigeria. International Journal of Scientific \& Technology Research, 1(8), 165-174.

Chu, H.-P., Chang, T., \& Sagafi-nejad, T. (2016). Globalization and Economic Growth Revisited: A Bootstrap Panel Causality Test. Cyrus Chronicle Journal, 1(1), 23-37. doi:10.21902/25735691/2016.v1i1.4 
Dickey, D. A., \& Fuller, W. A. (1981). Likelihood ratio statistics for autoregressive time series with a unit root. Econometrica: Journal of the Econometric Society, 1057-1072. doi:10.2307/1912517

Dogan, B., \& Deger, O. (2016). How Globalization and Economic Growth Affect Energy Consumption: Panel Data Analysis in the Sample of BRIC Countries. International Journal of Energy Economics and Policy, 6(4), 806-813.

Dreher, A. (2006). Does globalization affect growth? Evidence from a new index of globalization. Applied Economics, 38(10), 1091-1110. doi:10.1080/00036840500392078

Dreher, A., Gaston, N., \& Martens, P. (2008). Measuring Globalisation. Gauging its Consequences Springer, New York.

Elveren, A. Y., Örnek, İ., \& Akel, G. (2012). Internationalisation, growth and pay inequality: a cointegration analysis for Turkey, 1970-2007. International Review of Applied Economics, 26(5), 579-595. doi:10.1080/026921271.2011.624499

Engle, R. F., \& Granger, C. W. (1987). Co-integration and error correction: representation, estimation, and testing. Econometrica: Journal of the Econometric Society, 251-276. doi: $10.2307 / 1913236$

Ghosh, A. (2017). How does banking sector globalization affect economic growth? International Review of Economics \& Finance, 48, 83-97. doi:10.1016/j.iref.2016.11.011

Granger, C. W. (1969). Investigating causal relations by econometric models and cross-spectral methods. Econometrica: Journal of the Econometric Society, 424-438. doi:10.2307/1912791

Hamdi, F. (2013). The impact of globalization in the developing countries. Developing Country Studies, 3(11), 142-144.

Iqbal, J. (2011). Forecasting performance of alternative error correction models.

Johansen, S. (1988). Statistical analysis of cointegration vectors. Journal of economic dynamics and control, 12(2-3), 231-254. doi:10.1016/0165-1889(88)90041-3

Johansen, S. (1991). Estimation and hypothesis testing of cointegration vectors in Gaussian vector autoregressive models. Econometrica: Journal of the Econometric Society, 1551-1580. doi:10.2307/2938278

Johansen, S., \& Juselius, K. (1990). Maximum likelihood estimation and inference on cointegrationwith applications to the demand for money. Oxford Bulletin of Economics and statistics, $52(2)$, 169-210. doi:10.1111/j/1468-0084.1990.mp52002003.x

Kilic, C. (2015). Effects of Globalization on Economic Growth: Panel Data Analysis for Developing Countries. Petroleum-Gas University of Ploiesti Bulletin, Technical Series, 67(1).

Levy, B. (2012). The role of globalization in economic development. Available at SSRN 2233648. doi:10.2139/ssrn.2233648

Lo, D., Hong, F., \& Li, G. (2016). Assessing the role of inward foreign direct investment in Chinese economic development, 1990-2007: Towards a synthesis of alternative views. Structural Change and Economic Dynamics, 37, 107-120. doi:10.1016/j.strueco.2016.01.004

Moghaddam, A. A., \& Redzuan, M. R. (2012). Globalization and economic growth: A case study in a few developing countries (1980-2010). Research in World Economy, 3(1), 54 . doi:10.5430/rwe.v3n1p54

Nayyar, D. (2009). Developing countries in the world economy: the future in the past?

Ohlan, R. (2017). The relationship between tourism, financial development and economic growth in India. Future Business Journal, 3(1), 9-22. doi:10.1016/j.fbj.2017.01.003

Oyvat, C. (2010). Globalization, wage shares and income distribution in Turkey. Cambridge Journal of Regions, Economy and Society, 4(1), 123-138. doi:10.1093/cjres/rsq032

Patunru, A. A., \& Rahardja, S. (2015). Trade protectionism in Indonesia: Bad times and bad policy. 
Phillips, P. C., \& Perron, P. (1988). Testing for a unit root in time series regression. Biometrika, 75(2), 335-346. doi:10.1093/biomet/75.2.335

Rao, B. B., \& Vadlamannati, K. C. (2011). Globalization and growth in the low income African countries with the extreme bounds analysis. Economic Modelling, 28(3), 795-805. doi:10.1016/j.econmod.2010.10.009

Ray, S. (2012). Globalization and economic growth in India: A Granger causality approach. JL Pol'y \& Globalization, 2, 18 .

Salifou, C. K., \& Haq, I. u. (2017). Tourism, globalization and economic growth: a panel cointegration analysis for selected West African States. Current Issues in Tourism, 2o(6), 664-667. doi:10.1080/13683500.2016.1175421

Samimi, P., \& Jenatabadi, H. S. (2014). Globalization and economic growth: Empirical evidence on the role of complementarities. PloS one, $9(4)$, e87824. doi:10.1371/journal.pone.0o87824

Sargan, J. D. (1964). Wages and prices in the United Kingdom: a study in econometric methodology. Econometric analysis for national economic planning, 16, 25-54.

Schwarz, J., \& Mathijs, E. (2017). Globalization and the sustainable exploitation of scarce groundwater in coastal Peru. Journal of cleaner production, 147, 231-241. doi:10.1016/j.jclepro.2017.01.067

Shahzad, S. J. H., Shahbaz, M., Ferrer, R., \& Kumar, R. R. (2017). Tourism-led growth hypothesis in the top ten tourist destinations: New evidence using the quantile-on-quantile approach. Tourism management, 6o, 223-232. doi:10.1016/j.tourman.2016.12.006

Soren, J. (1995). Likelihood-based inference in cointegrated vector autoregressive models. OUP Catalogue.

Tambunan, T. T. (2010). The Indonesian experience with two big economic crises. Modern Economy, 1(03), 156. doi:10.4236/me.2010.13018

Tang, C. F., \& Tan, E. C. (2015). Does tourism effectively stimulate Malaysia's economic growth? Tourism management, 46, 158-163. doi:10.1016/j.tourman.2014.06.020

Toda, H. Y., \& Phillips, P. C. (1993). Vector autoregressions and causality. Econometrica: Journal of the Econometric Society, 1367-1393. doi:10.2307/2951647

Wu, T., Perrings, C., Kinzig, A., Collins, J. P., Minteer, B. A., \& Daszak, P. (2017). Economic growth, urbanization, globalization, and the risks of emerging infectious diseases in China: a review. Ambio, 46(1), 18-29. doi:10.1007/s13280-016-0809-2

Ying, Y.-H., Chang, K., \& Lee, C.-H. (2014). The impact of globalization on economic growth. Romanian Journal of Economic Forecasting, 17(2), 25-34. 